\title{
Chapter 2 \\ Growing Area of Sago Palm and Its Environment
}

\author{
Mochamad Hasjim Bintoro, Muhammad Iqbal Nurulhaq, \\ Agief Julio Pratama, Fendri Ahmad, and Liska Ayulia
}

\begin{abstract}
Sago palms grow well on riverbanks, near lakes, and in wet soil. They can be found at $700 \mathrm{~m}$ elevation in PNG and are well adapted in marginal soils where cash crops cannot grow. Sago palms can grow from low flooded areas to uplands and in soils which are from very acidic to neutral. Sago is one of the most efficient carbohydrate-producing crops. Sago is distributed naturally from Melanesia in the South Pacific in the east $\left(180^{\circ}\right.$ E. Long.) to India in the west $\left(90^{\circ} \mathrm{E}\right.$. Long.) and from Mindanao in the north $\left(10^{\circ} \mathrm{N}\right.$. Lat. $)$ to Java in the south $\left(10^{\circ} \mathrm{S}\right.$. Lat. $)$. Sago populations in the world occupy 2.4 million ha.

Temperature plays a key role in sago palm growth. The lowest temperature at which sago palms will grow is $15^{\circ} \mathrm{C}$. When temperatures are lower than $13{ }^{\circ} \mathrm{C}$ at the seedling stage, sago palms are not able to survive, and the mortality percentage increases. Moreover, fewer leaves are produced at low temperatures. The optimum relative humidity and sunlight intensity for sago palms are $90 \%$ and $900 \mathrm{j} / \mathrm{cm}^{2} /$ day. The optimum rainfall for sago is $2000 \mathrm{~mm}$ per year. In addition, sago can grow when the location has less than two dry months and more than nine wet months.

Sago palms can grow in various types of soils: (1) undeveloped soils, such as sulfaquents (sulfidic soil), hidraquents (waterlogged), tropaquents (tropical climate), fluvaquents (alluvial), and psammaquents (sandy soils), and (2) developed soils, such as tropaquepts, troposaprists of peatlands, tropohemists and sulfihemists (sulfuric soil and low $\mathrm{pH}$ ), and thaptohistic fluvaquents.

Sago palms thrive in swampy conditions where the pneumatophores are not submerged, where mineral nutrition and organic matter are high, and where the standing water is brown and slightly acidic. Such a habitat is suitable for the growth of microorganisms that benefit sago palm growth. Sago palms can also grow in swampy areas near the sea, as they are tolerant of salinity. Sago palms have avoidance tolerance to $\mathrm{Na}^{+}$. Excess $\mathrm{Na}^{+}$is stored in the roots.
\end{abstract}

M.H. Bintoro $(\bowtie) \bullet$ M. Iqbal Nurulhaq • A.J. Pratama • F. Ahmad • L. Ayulia Department of Agronomy and Horticulture, Faculty of Agriculture, Bogor Agricultural

University, Bogor, Indonesia

e-mail: hmh_bintoro@yahoo.com

H. Ehara et al. (eds.), Sago Palm, https://doi.org/10.1007/978-981-10-5269-9_2 
Subsidence will occur after peatlands have been drained, and the process occurs very quickly. Subsidence is approximately $20-50 \mathrm{~cm}$ year ${ }^{-1}$ during the early building of a drainage network. Land clearing for agricultural purposes is usually accompanied by the draining of peatlands. Drainage negatively impacts the soil by decreasing the soil level, which triggers the land's unavailability for agricultural use. Sago palm plantations can be a solution to the degradation of peatlands due to the maintenance of the water level. Sago palms grow optimally in swampy and waterlogged conditions and peatlands. Due to the maintenance of the water level during the sago palm growing period, the degradation of peatlands can be avoided. Sago palm cultivation on peat soil will conserve not only water but also soil, so the environment will be maintained. Sago palms also support peatlands in storing carbon and minimizing greenhouse effects. Moreover, sago palms have the highest $\mathrm{CO}_{2}$ absorption as compared to other major crops.

\subsection{The Origin of Sago Palm}

Sago palm (Metroxylon spp.) is a carbohydrate-producing plant, as are rice, corn, and tuber crops. Sago starch has potential as a food alternative and raw material for agroindustry due to its food resilience. Sago palm is a most productive plant, as compared with other carbohydrate-producing crops. The plant can produce 20-40 mt of dry starch ha ${ }^{-1}$ year $^{-1}$. Sago starch is sold by the farmers in coastal (lowland) areas. However, people outside the sago area assume that sago starch is not important. According to Ruddle (1979), approximately 300,000 people in Melanesia eat sago starch as a staple food, and some one million people consume it as a diet food.

Sago palm was first found and utilized by local people in Southeast Asia. According to Avé (1977) the sago palm is a multifunctional plant: its starch can be used as a staple food, and the pith residue as waste can be used as a medicine, a pesticide, and also as a poison for fish. Haryanto and Pangloli (1992) stated that people in some rural areas in Maluku Province eat sago starch as a staple food.

In Indonesia, sago can be found not only in Maluku but also in the Mentawai Islands in West Sumatra Province, Aceh, Riau Islands, Kalimantan, Sulawesi, Papua (Irian Jaya), West Papua (Irian Jaya Barat), and other provinces (Bintoro et al. 2013). According to Ruddle (1979), in the thirteenth century when Marco Polo went to Sumatra and Maluku, he found that the local people on some islands, i.e., Mentawai, Lingga, and Maluku, ate sago starch.

Sago palm is distributed across the southern part of Thailand, Malaysia, and Brunei and the southern part of the Philippines, Papua New Guinea (PNG), and the Solomon Islands (Ehara 2015). Because so many accessions can be found in those areas, Flach (1997) believes that the sago palm originated in Papua (Irian Jaya) and PNG. 
According to Yamamoto et al. (2005), approximately 15 accessions can be found around Sentani, Jayapura, with the differences in the accessions based on morphological characteristics and their adaptation to environmental conditions (Barahima 2006). Matanubun (2015) reported that there are 17 sago palm varieties and 10 subvarieties around Sentani Lake. Dewi et al. (2016) also found 12 sago varieties in Sayal Village, Saifi District. It is possible that many accessions in Papua and West Papua still have not yet been identified, although 96 varieties can be found in Waropen, Salawati, Wasior, Inanwatan, Onggari, Sentani, Kaureh, and Wandesi in Papua and West Papua (Matanubun et al. 2005). Further exploration of sago palms is needed.

Sago palms grow as a natural forest, especially in peat soil. The water in these areas is very acidic and brown in color. Those conditions are favorable for microorganisms with which sago palms are mutually beneficial (Bintoro et al. 2010). Sago palms grow well on riverbanks, near lakes, and in wet soil. They can be found at $700 \mathrm{~m}$ elevation in PNG and are well adapted in marginal soils where cash crops cannot grow. Notohadiprawiro and Louhenapessy (1992) stated that sago palms can grow from low flooded areas to uplands and in soils which are from very acidic to neutral.

\subsection{Sago Distribution}

Sago is one of the most efficient carbohydrate-producing crops. Sago is distributed from Melanesia in the South Pacific in the east $\left(180^{\circ}\right.$ E. Long.) to India in the west $\left(90^{\circ}\right.$ E. Long.) and from Mindanao in the north $\left(10^{\circ} \mathrm{N}\right.$. Lat.) to Java in the south $\left(10^{\circ} \mathrm{S}\right.$. Lat.) (Johnson 1977). Some of the countries with sago distribution include Indonesia, Malaysia, Papua New Guinea, the Philippines, and Thailand. The extent of sago distribution is different in each country, with Indonesia, Malaysia, and Papua New Guinea having the widest distribution. Metroxylon sagu Rottb., which is spineless, is commonly found in the western part of the archipelago, while the spiny M. rumphii Mart. (= M. sagu Rottb.) is found in the eastern part. The main sago regions in the archipelago are Papua, Maluku, Sulawesi (especially South, Central and Southeast Sulawesi), Kalimantan (especially West Kalimantan), and Sumatra (especially the Riau Islands). In Java, sago is limited to the West Bogor and Banten districts. In regions with less rainfall, such as Nusa Tenggara Barat and Nusa Tenggara Timor, sago trees are hard to find (Djoefrie 1999).

The sago palm is a native plant that has spread across several Indonesian islands, such as Papua, West Papua, Maluku, Kalimantan, Sulawesi, Sumatra, Java, and the Mentawai Islands. The extent and the type of sago cultivation spread across each island are slightly different. There are still natural sago forests as well as semicultivated forests. Most areas of sago palms in Papua and West Papua are sago forests that have not been managed or cultivated, which decreases overall sago productivity. According to Djoefrie (1999), sago palm forests are found in the lands from the coast to $1000 \mathrm{~m}$ elevation, along riverbanks, and around lakes or swampy 
areas. Other islands, such as the Meranti Islands District of Riau Province, have cultivated sago, so the area can be known with certainty. In Indonesia, sago is not distributed among sago plantations but found in the form of patches scattered among islands large and small, which makes it difficult to collect data regarding the extent of the sago distribution. In addition, sago-growing environments, riverbanks, and swampy areas, with sufficient water depth, are difficult for researchers to visit, and the density of sago forests constrains people wishing to go into them.

According to Flach (1997), sago populations in the world occupy 2.4 million ha. But according to Djoefrie et al. (2014), in the Papua area, sago occupies 4.7 million ha, and there are 510,000 ha in West Papua. When these data are combined, the extent of the sago distribution worldwide reaches 6.5 million ha. The sago palm distribution in Indonesia, consisting of $85 \%$ of the sago worldwide, is 5.5 million ha. Of that, as much as 95\% - 5.2 million ha - are in Papua and West Papua (Djoefrie et al. 2014) (Figs. 2.1 and 2.2), with 0.3 million ha spread over several islands in Indonesia. According to the head of the Meranti Islands District, smallholding sago farmers in that district account for 42,130 ha and sago plantations for 21,418 ha.

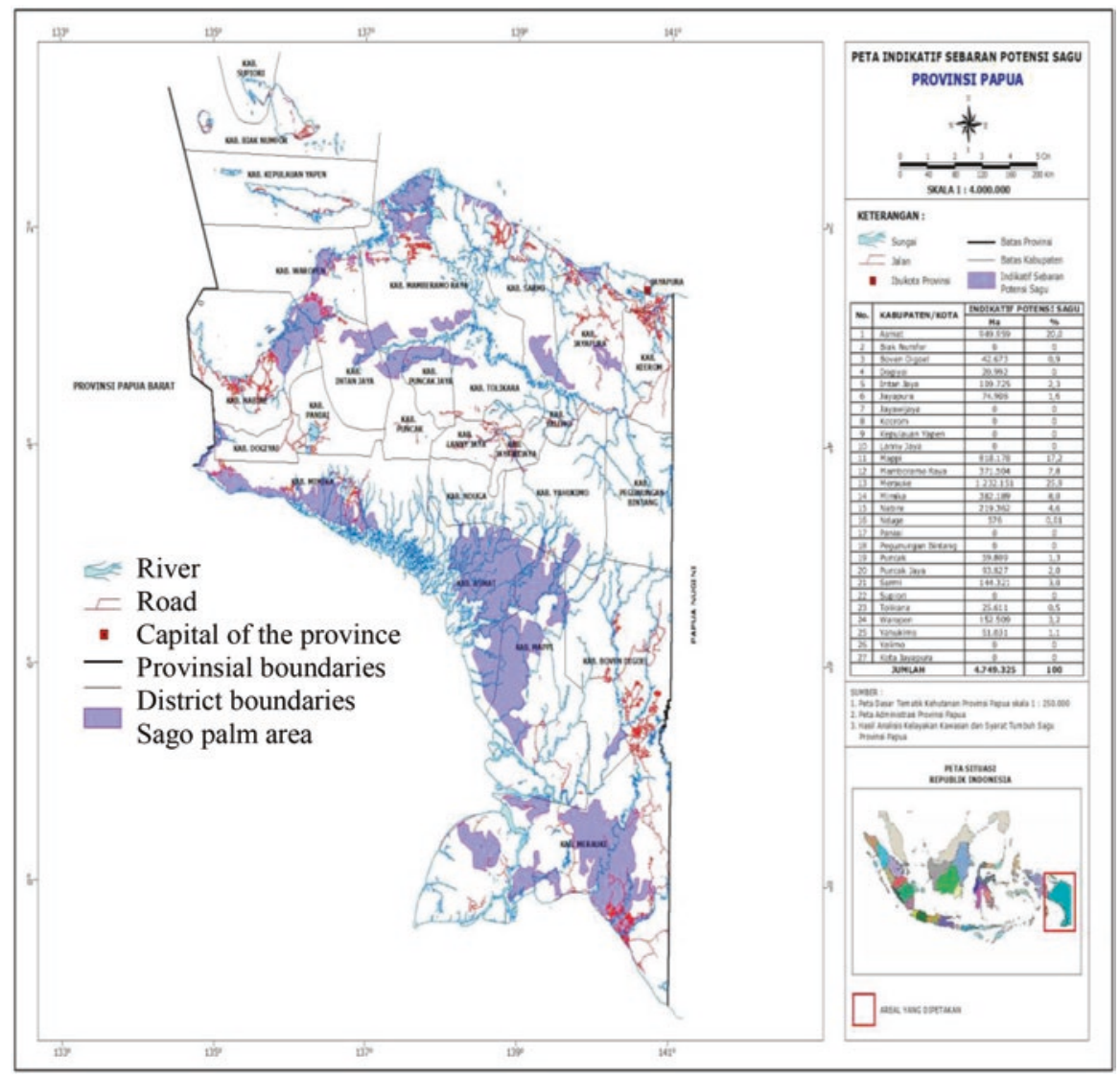

Fig. 2.1 Map of sago palm distribution in Papua 


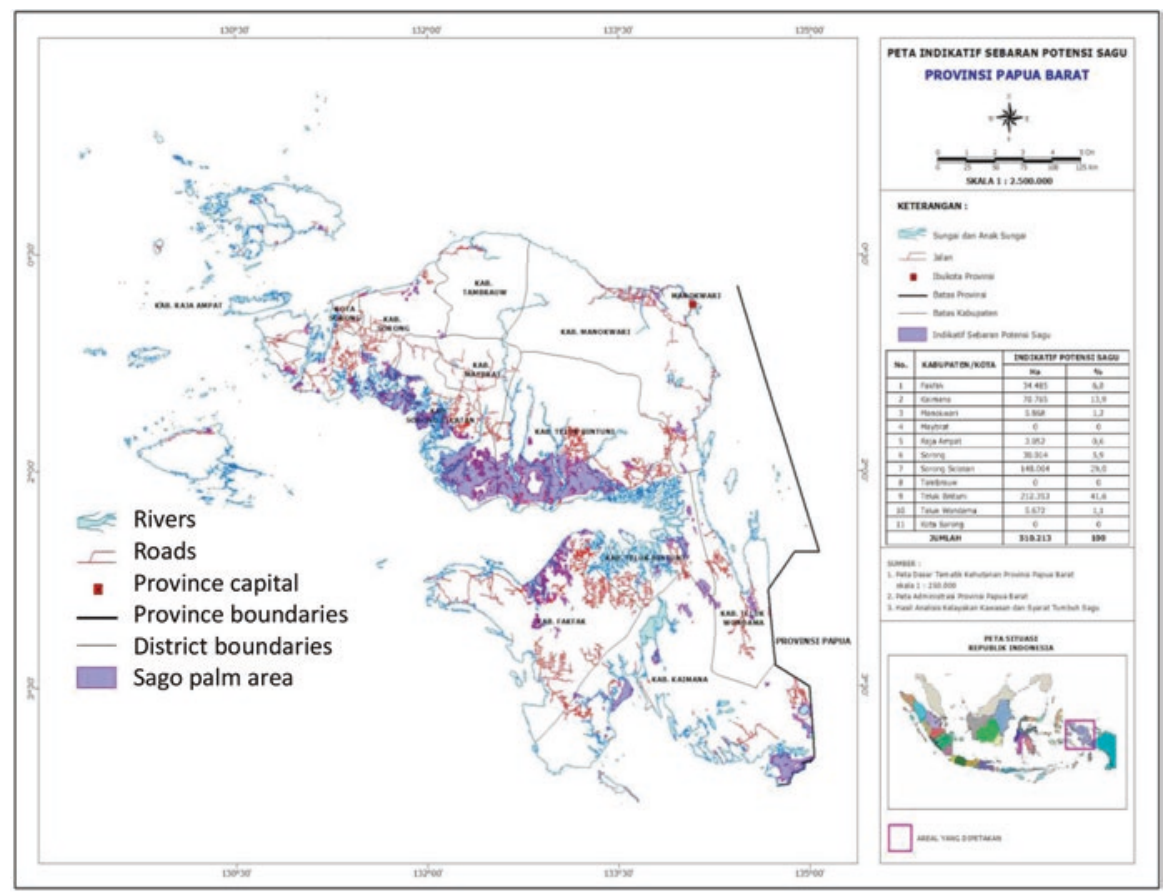

Fig. 2.2 The spread of sago palms in West Papua

The distribution of sago outside Indonesia is very diverse. Sago distribution in Thailand has reached 3000 ha (Flach 1997). According to Konuma, in 2008, as cited in Konuma (2014), sago grows in wetlands, along canals, and forests in southern Thailand. According to Jirasak et al. in 1996, cited in Konuma (2014), sago in Thailand grows on peatlands as sago forests located in the provinces of Narathiwat (50\%), Nakhon Si Thammarat (25\%), Songkhla (7.5\%), Chumporn (5\%), Phatthalung (4\%), and Pattani (2\%), with the remainder in Trat, Surat Thani, Trang, Phang Nga, Krabi, and Saturn. According to the Land Development Department of Thailand, peat swamps cover 64,000 ha and have the potential to become sago habitat, according to Klanarong in 1999, cited by Konuma (2014). According to Flach (1997), sago in Malaysia is in Sabah (10,000 ha), Sarawak (30,000 ha), and West Malaysia (5000 ha). Sago in Malaysia is already grown on plantations. Sago distribution in the Philippines has reached 3000 ha (Flach 1997). Santillan et al. (2012), using Landsat imagery in the province of Agusan del Sur, determined the total sago area to be 597 ha. The distribution of sago in Papua New Guinea is divided into two parts, sago forests (1 million ha) and semi-cultivated areas (20,000 ha) (Flach 1997). In Brunei Darussalam, sago is used as staple food and is second only to rice. Areas of sago production include the districts of Kuala Belait, Tutong, and Temburong (Ruddle 1979). The total area of sago in that district is not known with certainty. 


\subsection{Types of Sago Palms}

Sago palms are highly diverse. Papua has the highest diversity; and Indonesia is the earliest sago area (Abbas et al. 2009, 2010). This diversity is the result of crosspollination of the palm. Initially, there were described only five types of sago (four spiny types and one spineless); however, as observations carried out in the Moluccas Province continued, nine types of sago palms were described (Djoefrie 1999).

Random amplified polymorphism DNA (RAPD) analysis was used to identify the genetic links among sago palms. The results showed that the sago palms that originated in Papua are genetically linked to the sago from Kalimantan and the Sumatra Islands. The sago palm originally from Maluku is genetically correlated to the sago palm from Sulawesi Island, and the sago palm from Java is genetically related to those from other islands (Abbas et al. (2009). There was only one type of sago palm in Papua New Guinea, namely, Metroxylon sagu Rottb. (Kjaer et al. 2014). As they have the same genetic sequences (based on RAPD results), Hisajima in 1995, cited in Konuma (2014), reported that sago from Papua New Guinea spread to Thailand.

Local naming of sago palms is common in Indonesia. According to Djoefrie (1999) and Dewi et al. (2016), local people identify the palms by the presence or absence of spines, leaf color, bark, and bud color. A recent study showed that 12 accessions of sago palms in one district have wide ranging correlations and only 2 of 12 accessions are genetically correlated (Dewi et al. 2016).

Researchers have collected local names for sago varieties in various parts of Indonesia. Widjono et al. (2000) found 60 accessions of sago palms in Papua by the presence or absence of spines, bud color, leaf color, starch color, crown shape, stem diameter and long or short of spines, namely, Ana Apor, Ana Uwabu, Anangga Suanau, Ananggemo, Anaraumar Era, Anatuba Sianggono, Apaigo, Bibewo, Bibutu Mewi, Bosairo, Do Mboh, Edidao, Epesum, Epung Yepha, Fikta, Folio Hongleu, Folio Hongsay, Hanumbo, Hiyakhe, Hopholo Hongleu, Hopholo Hongsay, Igoto, Igoto Ogabarasu, Kambea, Kao, Manno Hongleu, Manno Hongsay, Marido, Merepo, Mongging, Okhu, Osokulu Hongleu, Osokulu Hongsay, Panne, Para Hongleu, Para Hongsay, Puy, Rondo Hongleu, Rondo Hongsay, Ruruna Hongleu, Ruruna Hongsay, Segago, To, Walisa Hongleu, Walisa Hongsay, Wanny Hongleu, Wanny Hongsay, and Wikuarawi. In addition, Dewi et al. (2016) found 12 accessions in Saifi by the shoots color, crown shape, trunk height, number of leaf, existence of spine, starch content, pith and starch color, West Papua-Fablen, Fafion, Failik, Fakattao, Fakreit, Falia, Fanke, Fanomik, Fasai, Fasampe, Fasinan, and Fasongka. According to Matanubun (2015), there are 23 accessions of sago palms in Sentani, Papua (13 with spines), namely, Phara (Phara Habou, Phara Hongsay, Phara Waliha), Mongging, Rondo (Rondo Hongsai, Rondo Honggeleu), Okhu, Pui, Yakhalobe, Ruruna, Ebhesum, Manno (Manno Fiho, Manno Parawakhe/Ohu), Yebha (Yebha Hongsai, Yebha Honggeleu, Ebhung Yebha), Osukhulu, Folo, Phane, Hobholo, Wani, Yakhe, and Hili. According to morphological characteristics, there are three types of sago palms in the Meranti Islands, namely, Sagu Sangka (rarely 
spiny), Sagu Bemban (having a spine), and sago palms with many spines (Novarianto et al. 2016). In Sorong, West Papua, there are five types of sago-Iwabinis, Iwayuluk, Iwarwo, Iwasnan, and Iwamuluk. According to Alfons and Bustaman in 2005, cited by Bintoro et al. (2013), Maluku has some five accessions of sagoDuri Rotan (Metroxylon microcanthum Mart. = M. sagu Rottb.), Ihur (M. sylvestre Mart. = M. sagu Rottb.), Makanaru (M. longispinum Mart. = M. sagu Rottb.), Molat (M. sagu Rottb.), and Tuni (M. rumphii Mart. = M. sagu Rottb.).

The genetic relationships of sago palms have been investigated by researchers. According to RAPD analysis, sago is classified into two main groups (A and B). Group A is divided into two subgroups (A1 and A2). Subgroup A1 consists of nine populations from Johor, eight from Sumatra and surrounding areas, one from Java, and two populations from Southwest Sulawesi. Subgroup A2 consists of three populations from Southwest Sulawesi and two from Mindanao, the Philippines. Group B consists of 12 populations from east Indonesia, 8 from the Seram, and 4 from the Ambon districts. Wakar accessions originated in Papua New Guinea, which is mapped out of the two main groups (Ehara et al. 2003).

\subsection{Ecology of the Sago Palm}

\subsubsection{Latitude and Climate}

The habitat of the sago palm is along rivers, lakes, and swamps. In addition, it adapts to land from sea level to $1200 \mathrm{~m}$ elevation (Schuiling 2009). The most suitable habitat for sago palms is below $400 \mathrm{~m}$ elevation. If sago is planted above $400 \mathrm{~m}$ elevation, it will grow slowly and have low productivity (Djoefrie 1999). Schuiling and Flach (1985) found that sago grown above $600 \mathrm{~m}$ elevation is shorter than $6 \mathrm{~m}$ and has a small trunk diameter.

Temperature plays a key role in sago palm growth. The lowest temperature at which sago palms will grow is $15^{\circ} \mathrm{C}$ (Bintoro et al. 2010). When temperatures are lower than $13{ }^{\circ} \mathrm{C}$ at the seedling stage, sago palms are not able to survive, and the mortality percentage increases. Moreover, fewer leaves are produced at low temperatures. For example, one leaf is produced at 25,20 , and $17^{\circ} \mathrm{C}$, over 20,25 , and 70 days, respectively (Flach et al. 1986; Schuiling 2009); and new leaves stop growing at temperatures below $17^{\circ} \mathrm{C}$ (Schuiling 2009).

The optimum relative humidity and sunlight intensity for sago palms are $90 \%$ and $900 \mathrm{j} / \mathrm{cm}^{2} /$ day (Notohadiprawiro and Louhenapessy 1992; Schuiling 2009; Bintoro et al. 2010). If sago is grown at temperatures below $20{ }^{\circ} \mathrm{C}$ and relative humidity of less than 70\%, starch production will drop by $25 \%$ (Notohadiprawiro and Louhenapessy 1992; Bintoro et al. 2010). Sago palms grown with low light intensity (less than $900 \mathrm{j} / \mathrm{cm}^{2}$ ) or under cloudy and shaded conditions produce less starch (Flach et al. 1986; Bintoro 2008).

The optimum rainfall for sago is $2000 \mathrm{~mm}$ per year (Okazaki and Kimura 2015). According to the Schmidt and Ferguson classification, sago palms are optimally 
grown in types A and B climates with rainfall between 2500 and $3500 \mathrm{~mm}$ and 142-209 days of rainfall per year (Turukay 1986). Moreover, according to the Oldeman (1980) classification, sago in Maluku and Papua grows in climate zones A, B1, B2, C1, C2, D1, D2, and E1. In addition, Notohadiprawiro and Louhenapessy (1992) stated that sago can grow when the location has less than two dry months and more than nine wet months.

In suboptimal conditions, sago palms need a longer time to reach maturity (the rosette phase). Under such conditions, the growth of new leaves is also slow, prolonging the time to maturity and therefore to starch production (Flach et al. 1986).

\subsubsection{Soil}

Sago palms can grow in various types of soils: (1) undeveloped soils, such as sulfaquents (sulfidic soil), hidraquents (waterlogged), tropaquents (tropical climate), fluvaquents (alluvial), and psammaquents (sandy soils), and (2) developed soils, such as tropaquepts, troposaprists of peatlands, tropohemists and sulfihemists (sulfuric soil and low $\mathrm{pH}$ ), and thaptohistic fluvaquents (Notohadiprawiro and Louhenapessy 1992).

Sago palms can grow on peatlands, with high organic matter (C-organic $>18 \%$ ). The depth of organic matter may exceed $50 \mathrm{~cm}$ (Agus and Subiksa 2008). In Malaysia, sago palms grow in peatlands, but they are less productive. Sago palms grown in peat soil have fewer leaves, only 17-19, while the number of leaves of sago palms grown in mineral soil can reach 20-24. The productivity per trunk is also less than of those grown in mineral soil (Flach and Schuiling 1991; Bintoro 2008). In peat soil, the sago palm harvest is more protracted than in mineral soil. In peat soil, sago can be harvested 12.7 years after planting, while in mineral soil, sago palm can be harvested 9.8 years after planting (Kueh et al. 1991). The dry starch content of sago palms grown in peat soil is approximately $88-179 \mathrm{~kg} /$ trunk, while the dry starch content of sago palms grown in mineral soil is approximately 123$189 \mathrm{~kg} / \mathrm{trunk}$ (Sim and Ahmad 1991). The production rate of sago palms grown in peat soil is $25 \%$ less than that of those grown in mineral soil (Kueh 1995). Yamamoto et al. (2003) observed the accumulation rate of sago palms cultivated in different types of soil.

Sago palms can also grow in volcanic, podzolic, grumosol, alluvial, and hydromorphic soil (Djoefrie 1999). According to Haryanto and Pangloli (1992), the growth of sago palms is inhibited in soil with insufficient microorganisms and nutrients. P, K, and Mg in water support sago palm growth. Extended waterlogged conditions inhibit starch formation.

Sago palms thrive in swampy conditions where the pneumatophores are not submerged, where mineral nutrition and organic matter are high, and where the standing water is brown and slightly acidic. Such a habitat is suitable for the growth of microorganisms beneficial to sago palm growth (Bintoro et al. 2010). 
Table 2.1 The influence of the hydrological status of water on the production of sago palm starch

\begin{tabular}{|c|c|c|c|c|}
\hline \multirow[b]{2}{*}{ No. } & \multirow{2}{*}{$\begin{array}{l}\text { Time logged } \\
\text { (months) }\end{array}$} & \multicolumn{2}{|l|}{ Logged } & \multirow{2}{*}{$\begin{array}{l}\text { Production } \\
\text { trunk }^{-1}(\mathrm{~kg})\end{array}$} \\
\hline & & Rainy season & Dry season & \\
\hline 1 & 12 & $+>7 \mathrm{~cm}$ & $+>10 \mathrm{~cm}$ & 94 \\
\hline 2 & $9-12$ & $+>50 \mathrm{~cm}$ & $-<10 \mathrm{~cm}$ & 192 \\
\hline 3 & $9-12$ & $+>50 \mathrm{~cm}$ & $-(10-40) \mathrm{cm}$ & 137 \\
\hline 4 & $9-12$ & $+(10-50) \mathrm{cm}$ & $-(10-40) \mathrm{cm}$ & 216 \\
\hline 5 & $6-9$ & $+>50 \mathrm{~cm}$ & $-(10-40) \mathrm{cm}$ & 348 \\
\hline 6 & $6-9$ & $+(10-50) \mathrm{cm}$ & $-(10-40) \mathrm{cm}$ & 328 \\
\hline 7 & $6-9$ & $+(10-50) \mathrm{cm}$ & $-(50-100) \mathrm{cm}$ & 273 \\
\hline
\end{tabular}

Logged (+) is the mean flooding, logged (-) is the mean beneath the soil surface Source: Notohadiprawiro and Louhenapessy 1992

Sago palms can also grow in swampy areas near the sea, as they are tolerant of salinity. Sago palms have avoidance tolerance to $\mathrm{Na}^{+}$. Excess $\mathrm{Na}^{+}$is stored in the roots. According to Yoneta et al. (2006), high salinity (> $200 \mathrm{mM} \mathrm{NaCl}$ ) inhibits photosynthesis. The ability of sago palms to grow in swampy areas is very important to their economic development.

The hydrological status influences sago palm growth (Table 2.1). The soil water depth is approximately $30-50 \mathrm{~cm}$ beneath the soil surface. According to Djoefrie (1999), the most interesting fact about the sago palm is its ability to grow in areas where other plants cannot be cultivated. Sago palms can grow in waterlogged soil of more than $1 \mathrm{~m}$ depth.

\subsection{Sago Palm's Role in the Environment}

\subsubsection{Soil Subsidence}

Subsidence will take place after peatlands have been drained, and the process occurs very quickly. Subsidence is approximately $20-50 \mathrm{~cm}$ year $^{-1}$ during the early building of a drainage network (Welch and Nor 1989).

Agus and Subiksa (2008) explain that the subsidence process consists of four components:

1. Consolidation: peat consolidates because of the influence of drainage. Decreasing water levels in peat soil will increase the pressure of the peat above the soil surface as compared to the peat below the water surface. Therefore, the peat becomes compacted.

2. Lyses: decreased peat volume above the water soil surface due to the drainage process.

3. Decomposition: decreased peat volume due to the decomposition process of the aerobic condition.

4. Burning: causes a decreased volume of peat. 
Land clearing for agricultural purposes is usually accompanied by the draining of peatlands. Drainage negatively impacts the soil by decreasing the soil level, which triggers the land's unsuitability for agricultural use. The soil level in the peatlands can be reduced by $3 \mathrm{~m}$ in 30 years (Bintoro et al. 2013).

Sago palm plantations can be a solution to the degradation of peatlands due to the maintenance of the water level. Sago palms grow optimally in swampy and waterlogged conditions and peatlands (Bintoro et al. 2013). During the growing period, sago palms need waterlogged conditions, as shown by the green color of the leaves, to produce suckers. Due to the maintenance of the water level during the sago palm growing period, the degradation of peatlands can be avoided.

\subsubsection{Water Conservation}

The conservation of peatlands is important because they are decreasing in area in some parts of Indonesia. In 1952, Pulau Petak Delta had 51,360 ha of peatlands; however, by 1972, peatlands in the same area had been reduced to 26,400 ha and further dwindled to 9600 ha in 1992 (Sarwani and Widjaja-Adhi 1994). Growing sago palms is a solution to overcoming peatland degradation because they do not need soil drainage and they tolerate waterlogging. Sago palms can conserve soil water because the plants require high soil humidity. Areas that are sometimes flooded are suitable for sago palms. Areas for sago palms must conserve high soil humidity; however, if the area will be used for other crops, the water must be drained away to the river or the sea. Sago palm areas have abundant water; humans, cattle, and vegetation/crops need water (Bintoro et al. 2010). Sago palm cultivation on peat soil will conserve not only water but also soil, so the environment will be maintained.

\subsubsection{The Absorption of $\mathrm{CO}_{2}$}

Climate change can be diminished by agricultural practices and the cultivation of sago palms. The ability of sago palms to absorb $\mathrm{CO}_{2}$ is important for maintaining the environment. According to Indonesian Presidential Decree No. 5 in 2006, regarding the national energy obligation to decrease emissions to $17 \%$ in 2025 , steps that can be applied in the face of climate change include the conservation of forests, seas, and agricultural areas, which can decrease $\mathrm{CO}_{2}$ emissions and reduce the greenhouse effect.

Swamps and peatlands are related to global warming. This is because swampy areas can store large amounts of carbon, which can decrease gas emissions in the atmosphere. Open peatlands expose the soil surface to the sun, which triggers the release of $\mathrm{CO}_{2}$ emissions and $\mathrm{CH}_{4}$ to the atmosphere. The increasing amount of $\mathrm{CO}_{2}$ and $\mathrm{CH}_{4}$ can trigger the greenhouse effect, increasing temperatures, and rising sea 
Table 2.2 Capability of $\mathrm{CO}_{2}$ absorption of major crops

\begin{tabular}{l|l|l|l|l|l|l}
\hline & $\begin{array}{l}\text { Average } \\
\text { of harvest } \\
\text { year }^{-1}\end{array}$ & $\begin{array}{l}\text { Average } \\
\text { number of } \\
\text { effective day } \\
\text { cycle }\end{array}$ & $\begin{array}{l}\text { Day } \\
\text { length } \\
\text { (hour) }\end{array}$ & $\begin{array}{l}\text { Photosynthesis } \\
\mathrm{CO}_{2} \mathrm{~m}^{-2} \mathrm{~h}^{-1}(\mathrm{mg})\end{array}$ & $\begin{array}{l}\text { Leaf } \\
\text { coverage } \\
(\mathrm{million} \\
\text { ha) }\end{array}$ & $\begin{array}{l}\mathrm{CO}_{2} \\
\mathrm{Absorption} \\
\mathrm{mt} \mathrm{ha}^{-1} \mathrm{year}^{-1}\end{array}$ \\
\hline Sago & 1 & 365 & 12 & 22 & 3 & 289 \\
\hline Corn & 2.5 & 45 & 13 & 80 & 2 & 216 \\
\hline Rice & 2.5 & 45 & 14 & 30 & 2 & 81 \\
\hline Cassava & 1 & 180 & 15 & 39 & 2 & 168 \\
\hline Sugarcane & 1 & 180 & 16 & 52 & 2 & 225 \\
\hline $\begin{array}{l}\text { Sweet } \\
\text { potato }\end{array}$ & 2 & 80 & 17 & 23 & 3 & 88 \\
\hline
\end{tabular}

Source: (BPPT 2008) cited in (Bintoro et al. 2010)

levels. According to Bintoro et al. (2010), gas emissions of $\mathrm{CO}_{2}$ and $\mathrm{CH}_{4}$ from peatlands vary from $25-200 \mathrm{mgm}^{2-1} \mathrm{~h}^{-1}$, and the rate of the photosynthesis of sago is $22 \mathrm{mg} \mathrm{CO} \mathrm{dm}^{2-1} \mathrm{~h}^{-1}$. According to calculations, sago palms can absorb $240 \mathrm{mt}$ of $\mathrm{CO}^{2} \mathrm{ha}^{-1}$ year $^{-1}$. Sago palms also support peatlands in storing carbon and minimizing greenhouse effects. Sago palms cover 5,259,538 ha in Papua and West Papua provinces and can absorb some 1,262,289,120 mt of $\mathrm{CO}_{2}$ (Bintoro et al. 2010). Moreover, sago palms have the highest $\mathrm{CO}_{2}$ absorption as compared to other major crops (Bintoro et al. 2010), as shown in Table 2.2.

\section{References}

Abbas B, Bintoro MH, Sudarsono et al (2009) Genetic relationship of sago palm (Metroxylon sagu Rottb.) in Indonesia based on RAPD markers. Biodiversitas 10(4):168-174

Abbas B, Renwarin Y, Bintoro MH et al (2010) Genetic relationship of sago palm in Indonesia based on chloroplast DNA (cpDNA) markers. Biodiversitas 11(3):112-117

Agus F, Subiksa IGM (2008) Lahan gambut: potensi untuk pertanian dan aspek lingkungan. balai penelitian tanah dan World Agroforestry Centre (ICRAF). Bogor (in Indonesian)

Avé JB (1977) Sago in insular Southeast Asia: historical aspects and contemporary use. Tan K, (ed) Sago-76 papers of the first international sago symposium. Kuching, July 5-7, 1976, pp 21-30

Barahima (2006) Keragaman genetic tanaman sagu di Indonesia berdasarkan penanda molekuler genom, kloroplas dan genom inti [disertasi]. Bogor (ID): Institut Pertnian, Bogor

Bintoro HMH (2008) Bercocok tanam sagu. IPB Press, Bogor. 71 hal. (in Indonesian)

Bintoro HMH, Purwanto YJ, Amarillis S (2010) Sagu di lahan gambut. IPB Press, Bogor. (in Indonesian)

Bintoro MH, Amarillis S, Dewi RK, Ahyuni D (2013) Sagu mutiara hiaju khatulistiwa yang dilupakan. Digreat Publishing, Bogor. (in Indonesian)

BPPT (2008) Sagu, potensial perkaya keragaman pangan (http://www.bppt.go.id) 13 March 2008

Dewi RK, Bintoro MH, dan Sudradjat (2016) Morphological characteristics and yield potential of sago palm (Metroxylon spp.) accessions in south Sarong District, West Papua. J Agron Indonesia 44(1):91-97. (in Indonesian)

Djoefrie HMHB (1999) Pemberdayaan tanaman sagu sebagai penghasil bahan pangan alternatif dan bahan baku agroindustri yang potensial dalam rangka ketahanan pangan nasional. Orasi 
Ilmiah Guru Besar Tetap Ilmu Tanaman Perkebunan Fakultas Pertanian Institut Pertanian Bogor, Bogor. 69 hal (in Indonesian)

Djoefrie MHB, Herodian S, Ngadiono et al (2014) Sagu untuk kesejahteraan masyarakat Papua: suatu kajian dalam upaya pengembangan sagu sebagai komoditas unggulan di Provinsi Papua dan Papua Barat. Laporan Penelitian. Jakarta, Unit Percepatan Pembangunan Papua dan Papua Barat. $192 \mathrm{hlm}$ (in Indonesian)

Ehara H (2015) Origin, dispersal and distribution. In: The sago palm: the food and environment challenges of the 21 st century. The Society of Sago Palm Studies, Kyoto, Kyoto University Press, pp 1-30

Ehara H, Kosaka S, Shimura N et al (2003) Relationships between geographical distribution and genetic distance of sago palm in Malay Archipelago. Sago Palm 11:8-13

Flach M (1997) Sago palm Metroxylon sagu Rottb. IPGRI, Rome

Flach M, Braber KD, Fredrix MJJ et al (1986) Temperature and relative humidity requirements of young sago palm seedlings. In: Yamada N, Kainuma K (eds) Proceedings of the third international sago symposium. Sago Palm Research Fund, Tokyo, pp 139-143

Flach M, Schuiling DL (1991) Growth and yield of sago palms in relation to their nutritional needs. In: Ng TT, Tie YL, Kueh HS (eds) Proceedings of the fourth international sago symposium, Kuching, Sarawak, Malaysia. Lee Ming Press, Kuching, pp 103-110

Haryanto B, Pangloli P (1992) Potensi dan pemanfaatan sagu. Penerbit Kanisius Jogjakarta (in Indonesisn)

Johnson D (1977) Distribution of sago making in the old world. In: Tan K (ed) Proceedings of the first international sago symposium, Kuching, July 5-7, 1976, pp 65-75

Kjaer A, Barfod AS, Asmussen CB, Seberg O (2014) Investigation of genetic and morphological variation in the sago palm (Metroxylon sagu; Arecaceae) in Papua New Guinea. Ann Bot 94(1):109-117

Konuma H (2014) Studies on the characteristics of sago starch in relation to growth environment of sago palm (Metroxylon sagu Rottb.) and its value addition to wheat flour as a food starch ingredient. Dissertation, University of Tsukuba, Japan

Kueh HS (1995) The effect of soil applied NPK fertilizers on the growth of the sago palm (Metroxylon sagu Rottb.) on undrained deep peat. Acta Hort 389:67-76

Kueh HS, Elone R, Yiu-Liong T et al (1991) The feasibility of plantation production of sago (Metroxylon sagu) on an organic soil in Sarawak. In: Ng TT, Tie YL, Kueh HS (eds) Proceedings of the fourth international sago symposium, Kuching, Sarawak, Malaysia. Lee Ming Press, Kuching, pp 127-136

Matanubun H (2015) Folk taxonomy of sago palm varieties around Sentani Lake, Jayapura, Papua Province, Indonesia. In: Paper presented at the 12th international sago symposium, Tokyo, September 15-16, 2015

Matanubun H, Santoso B, Nauw M et al (2005) Feasibility study of the natural sago forest for the establishment of the commercial sago palm plantation at Kaureh District, Jayapura, Papua Province Indonesia. In: Proceedings of the 8th international sago symposium, August 4-6, 2005. Universitas Negeri Papua, Manokwari, Indonesia

Notohadiprawiro T, Louhenapessy JE (1992) Potensi sagu dalam penganekaragaman bahan pangan pokok ditinjau dari persyaratan lahan. Prosiding Simposium Sagu Nasional. Fakulas Pertanian Universitas Pattimura. Ambon. Hal, pp 99-106 (in Indonesian)

Novarianto H, Tulalo MA, Kumaunang J et al (2016) Seleksi dan pelepasan varietas selatpanjang meranti untuk pengembangan sagu. J Metroxylon Indonesia 1(1):1-9. (in Indonesian)

Okazaki M, Kimura SD (2015) Ecology of the sago palm. In: The sago palm, the food and environmental challenges of the 21st century. The Society of Sago Palm Studies, Kyoto University Press, pp 41-60

Oldeman LR (1980) The agroclimatic maps of Kalimantan, Maluku, Irian Jaya and Bali, West and East Nusa Tenggara. Central Research Institute for Agriculture, Bogor

Ruddle K (1979) The geographical distribution of sago-producing palms. National Museum of Ethnology, pp 572-594 
Santillan JR, Santillan MM, Francisco R (2012) Using remote sensing to map the distribution of sago palms in northeastern Mindanao, Philippines: Results based on Landsat ETM+ image analysis. The 33rd Asian Conference on Remote Sensing. November 26-30, 2012, Pattaya, Thailand

Sarwani M, Widjaja-Adhi IPG (1994) Penyusutan lahan gambut dan gampaknya terhadap produktivitas lahan pertanian di sekitarnya. Kasus Delta Pulau Petak Kalimantan Selatan. Prosiding Seminar Nasional 25 Tahun Pemanfaatan Lahan Gambut dan Pengembangan Kawasan Pasang Surut. December 14-15, 1994, Jakarta (in Indonesian)

Schuiling DL (2009) Growth and development of true sago palm (Metroxylon sagu Rottboll.) with special reference to accumulation of starch in the trunk. Thesis. Wageningen University, Wageningen

Schuiling DL, Flach M (1985) Guidelines for the cultivation of sago palm. Department Tropical Crop Science, Agricultural University, Wageningen

Sim ES, Ahmed MI (1991) Leaf nutrient variations in sago palms. In: Ng TT, Tie YL, Kueh HS (eds) Proceedings of the fourth international sago symposium, Kuching, Sarawak, Malaysia. Lee Ming Press, Kuching, pp 92-102

Turukay B 1986 The role of the sago palm in the development of integrated farm system in Maluku Province of Indonesia. In: Uamada N, Kainuma K (eds) Proc. 3rd int. sago symp. Tokyo, May 20-23, 1985, pp 7-15

Welch DN, Nor MAM (1989) Drainage works on peat in relation to crop cultivation-a review of problems. Malaysian Soc. Soil Sci. National Seminar on Soil Management for Food and Fruit Crop Production, March 1989, Kuala Lumpur, pp 28-29

Widjono A, Mokay Y, Amisnaipa et al (2000) Jenis-jenis sagu beberapa daerah Papua. Pusat Penelitian dan Pengembangan Sosial Ekonomi Pertanian, Bogor, pp 61-64. (in Indonesian)

Yamamoto Y, Yoshida T, Goto Y et al (2003) Differences in growth and starch yield of sago palms (Metroxylon sagu Rottb.) among soil types in Sarawak, Malaysia. Jpn J Trop Agr 47: 250-259

Yamamoto Y, Yoshida T, Miyazaki A et al (2005) Biodiversity and productivity of several sago palm varieties in Indonesia. In: Abstract of the eighth international sago symposium in Jayapura, Indonesia. Japan Society for the Promotion Science

Yoneta R, Okazaki M, Yano Y (2006) Response of sago palm (Metroxylon sagu Rottb.) to $\mathrm{NaCl}$ stress. Sago Palm 14:10-19

Open Access This chapter is licensed under the terms of the Creative Commons Attribution 4.0 International License (http://creativecommons.org/licenses/by/4.0/), which permits use, sharing, adaptation, distribution and reproduction in any medium or format, as long as you give appropriate credit to the original author(s) and the source, provide a link to the Creative Commons license and indicate if changes were made.

The images or other third party material in this chapter are included in the chapter's Creative Commons license, unless indicated otherwise in a credit line to the material. If material is not included in the chapter's Creative Commons license and your intended use is not permitted by statutory regulation or exceeds the permitted use, you will need to obtain permission directly from the copyright holder.

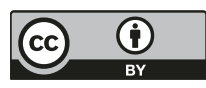

